\title{
Evaluation of the Soil Response to the Successive Application of Aqueous Extracts from Canavalia Ensiformis Leaves Used as a Post-emergent Bioherbicide
}

\author{
Darlan Ferreira Silva (Corresponding author) \\ Chemistry Institute of São Carlos, University of São Paulo, \\ Avenida Trabalhador São Carlense, São Carlos-SP 13566 590, Brazil. \\ E-mail: darlanveggito@hotmail.com
}

\begin{abstract}
Maria Olimpia Oliveira Rezende
Department of Chemistry, Chemistry Institute of São Carlos, University of São Paulo, Avenida Trabalhador São Carlense, São Carlos-SP 13566 590, Brazil.
\end{abstract}

Received: July 20, 2017

doi:10.5296/jas.v5i3.11574
Accepted: August 6, 2017

Published: August 17, 2017

URL: https://doi.org/10.5296/jas.v5i3.11574

\begin{abstract}
Soil is normally the final destination of pesticides applied to cultures. After a series of applications, various pesticides reach the soil due to direct application or leaf washing. However, some amount of the pesticides, particularly foliar pesticides, are intercepted and absorbed by the leaves of the weeds or by the culture itself. Plants contaminated with pesticides may return to the soil during the culture cycle (leaf senescence) or after harvesting (as crop residues). The destination of the pesticide residues in the soil from plant material is both generally ignored and unknown. The pesticide and its degradation products can be released into the soil during the decomposition of the plant, leading to an additional risk of environmental contamination. The greatest consideration when using pesticides (herbicides, insecticides, etc.) is the sensitivity and danger to other non-target species and organisms in the area of application. The adverse effects caused by the indiscriminate use of pesticides,
\end{abstract}


especially herbicides, receive substantial attention because they account for $45 \%$ of the world's total pesticide market. In this work, Tukey's test was used (with a 5\% level of probability) to compare soil responses to successive applications of aqueous extracts containing bioherbicides. In general, the existence of bioherbicide residues in soil did not change its properties relative to a control soil. The nutrients evaluated herein did not show a tendency to decrease or increase in concentration during successive applications of the extracts onto the weeds, including possible contact with the soil. The use of bioherbicide did not interfere with the availability of the nutrients or affect the soil fertility characteristics, and it consequently promoted the development of plants throughout the experiment. The persistence of the bioherbicide or its byproducts in soil should not be considered an environmental risk.

Keywords: Soil, Bioherbicide, Weeds, Contamination, Canavalia ensiformis

\section{Introduction}

Jack-bean (Canavalia ensiformis) is a fast-growing plant used as a green cover; it is considered a rustic plant due to its great tolerance to a wide range of soil $\mathrm{pH}$, as well as to other environmental problems. Jack-bean is able to associate with nitrogen-fixing bacteria and mycorrhizal fungi and, thus, ameliorate the soil by improving its fertility. It is native to the tropics and subtropics of South America, especially in low altitude regions with high temperatures and a high relative humidity (Silva and Rezende, 2016; Andrade et al., 2010).

Herbicides represent the most marketed class of pesticides in the world. In Brazil, sales of herbicides represent approximately $45 \%$ of the whole market for pesticides (EMBRAPA, 2009).

The use of herbicides is the most employed strategy to combat infestation by weeds; however, in Brazil, their continuous and intensive use raises concerns about the sustainability of soil fertility. The contact of herbicides with soil not only changes the effectiveness of an herbicide against weed growth but also affects the cycle of various nutrients, resulting in the variation of the enzymatic activity of the soil (Singh and Ghoshal, 2013).

Herbicides applied to crops, both pre- and post-emergence, often ultimately accumulate in the soil. Upon reaching the soil, these compounds may be retained by colloids or remain in the soil solution. The soil has the ability to retain organic molecules, preventing them from moving either into or out of the soil matrix. Retention is the adsorption and absorption by the soil matrix when the plants in the soil are considered, and it competes with degradation by microorganisms. Additionally, retention is controlled by chemical and biological transformations and influenced by the transport of the organic molecules to the atmosphere, groundwater and surface. Thus, retention is the factor that determines the efficiency of a pesticide in soil (Oliveira, Brighenti, 2011).

Agricultural pests have the ability to develop resistance to applied formulations, which, over time, causes a pesticide to lose its effectiveness and stimulates farmers to increase the applied doses or to search for new products. Another important element in the process of combating agricultural pests is the environmental unbalance these techniques cause, which leads to the 
emergence of new pests and even changes in the behavior of plants (i.e., those that did not originally damage crops can begin to behave as weeds). Therefore, it is of great importance that smaller amounts of herbicides are used on plantations, which search for less environmentally toxic formulations while waiting for the development of new compounds. Thus, the use of natural substances to combat pests and weeds could be a good alternative for control and prevention of environmental contamination (Silva and Rezende, 2016).

In this work, possible chemical changes in the soil were evaluated after successive applications of aqueous extracts obtained from the leaves of a Canavalia ensiformis plant used as a post-emergent bioherbicide in order to control Emilia sonchifolia and Sida spinosa weeds in conventional soybean cultivation. Emilia sonchifolia is a widely disseminated weed across almost all of Brazil (Yamashita et al., 2009); Sida spinosa is an erect annual shrub that is widely spread along the banks of highways, rivers and lakes.

\section{Materials and Methods}

\subsection{Greenhouse Experiment}

The study was conducted in a greenhouse located on the campus of the University of São Paulo in the city of São Carlos, where temperatures ranged from 20 to $38{ }^{\circ} \mathrm{C}$ throughout the tests. The soil used in the experiments was silt-loam (58.7\% clay, $29.0 \%$ silt and $13.0 \%$ sand) and was collected near the Luiz Augusto de Oliveira Highway, whose coordinates are latitude $22^{\circ} 0^{\prime} 41.60$ 'S, longitude 47 59'30.7'W. The seeds of the weeds (Emilia sonchifolia and Sida spinosa) were purchased from a local agricultural store. Conventional soybean seeds (Cultivar BRS-283) were supplied by EMBRAPA Soja, Londrina-PR.

The experimental units comprised 20 vases of 10 L capacity, each of which was filled up with soil containing an average of 7 to 8 soybean plants and 5 to 6 weeds. The experiment was run in 5 triplicates, with one vase used as a control in each triplicate. Extracts of leaves from jack-bean were applied to the conventional soybean plants (cultivar BRS-283) and to the Emilia sonchifolia and Sida spinosa weeds. All treatments were compared to the control vase (no extract application) during the evaluation steps.

Visual assessments of the bioherbicide effects were performed according to the conceptual scale of the Brazilian Society Science of Weeds (SBCPD, 1995) and weed control according to Latin American Weed Association (ALAM, 1974). In the soybean plants, foliar application of the extracts containing the prospective bioherbicide was enough to cause visible changes within approximately 24 hours. Therefore, the experiment was accomplishment only with direct application of the extracts onto the weeds (Silva and Rezende, 2016).

The extract was applied post-emergence (after germination of the weed seeds). The aqueous extracts were applied with a device that sprayed the liquid so that it reached the entire foliar surface of the weeds. The extracts were stored at $4{ }^{\circ} \mathrm{C}$ between applications. The extracts were applied in pre-defined time intervals $(0,15,30,45$ and 60 days), where time 0 corresponds to the first application after the first germination of the weed seeds. 


\section{Macrothink}

\subsection{Preparation of the Extracts for Application}

The extract containing the bioherbicide was prepared by Microwave-Assisted Extraction (MAE) according to the method of Silva and Rezende (2016). Thus, after the extraction procedure, the material was filtered through a $45 \mu \mathrm{m}$ filter paper and concentrated in a rotary evaporator $\left(70 \mathrm{rpm}\right.$ at $70{ }^{\circ} \mathrm{C}$ ). The final mass was weighed, and the aqueous extracts were prepared by adding deionized water to obtain a concentration of $200 \mathrm{~g} \mathrm{~L}^{-1}$.

\subsection{Procedure for the Application of the Extracts}

The extract containing the bioherbicide was applied post-emergence of the weeds. Changes in the soil were evaluated by the 'Days After Application' (DAA) of the extracts on the weeds, counted from the first application.

Every 15 days, $3 \mathrm{~mL}$ per weed of the extract was applied at a concentration of $200 \mathrm{~g} \mathrm{~L}^{-1}$. Four vases (one triplicate + one control) were removed from the experiment for soil analysis. Subsequently, a new application was conducted on the remaining vases of the experiment. Thus, it was possible to evaluate the action of the bioherbicide after successive applications and possible bioaccumulation in the soil over time. The last sampling for chemical analyzes occurred at 60 days. After that, the last four vases were visualized observed for 15 more days.

The results of the soil analysis were labeled DAA15, DAA30, DAA45 and DAA60, referring to the days when the soil was collected and analyzed, and time zero refers to the soil analysis performed before the first application of the bioherbicide.

\subsection{Soil Preparation for Analysis}

The soil samples were collected directly from the experimental units. A set of simple samples were taken from random points approximately $20 \mathrm{~cm}$ deep to form a composite sample of approximately $500 \mathrm{~g}$. The collected soil was dried at room temperature, manually cleaned to remove roots and remaining plants, and sieved $(2 \mathrm{~mm})$ for homogenization to obtain a fraction of the dry soil for chemical characterization.

Figure 1 shows a diagram of the analytical stages of the initial experiment (i.e., before planting), progressing from the first application to the fourth application of the extracts onto the weeds. 


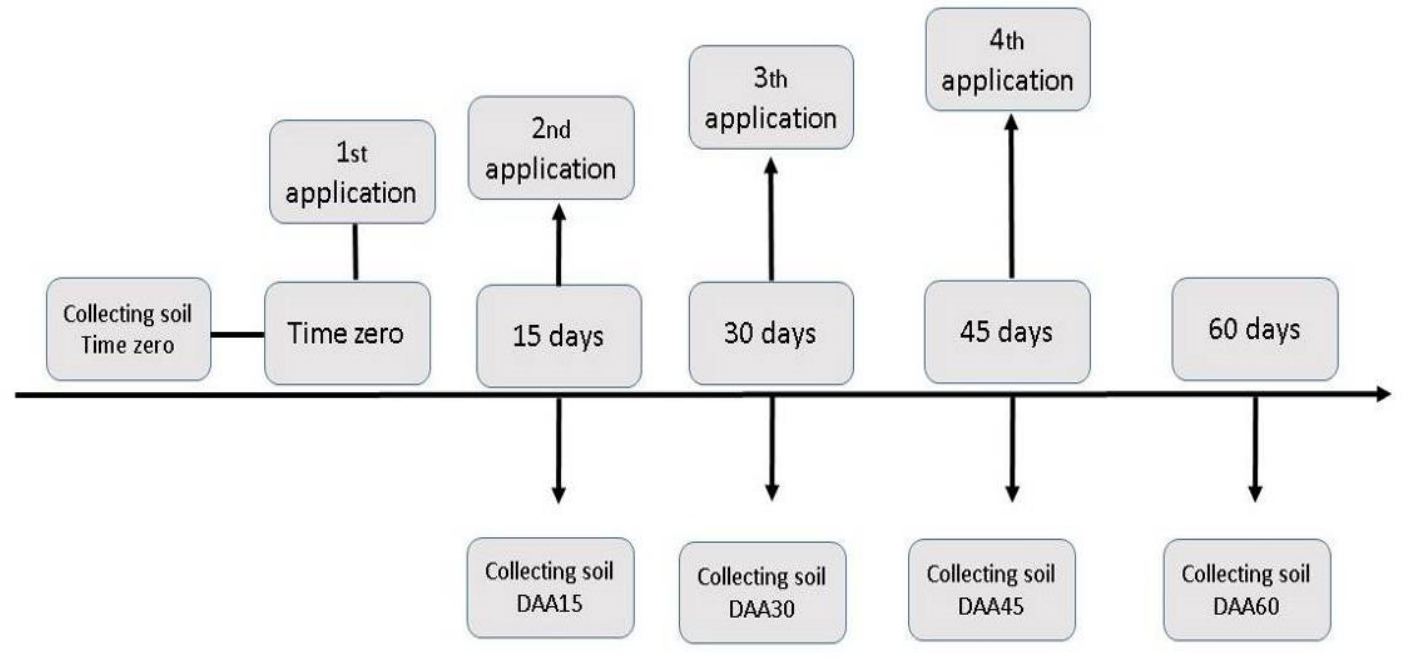

Figure 1. Stages of the experiment.

\subsection{Chemical Analysis of the Soil}

The chemical analyses of the soil were conducted before the beginning of the experiments and after each application of extract. For soil $\mathrm{pH}$ evaluation, $10 \mathrm{~g}$ of dry sample was weighed, and $25 \mathrm{~mL}$ of $0.01 \mathrm{~mol} \mathrm{~L}^{-1} \mathrm{CaCl}_{2}$ solution was added (Fassbender, 1975).

For soil calcium and potassium evaluation, $12.5 \mathrm{~g}$ of dry sample were weighed and $125 \mathrm{~mL}$ of ammonium acetate solution ( $\mathrm{pH} \mathrm{7)} \mathrm{was} \mathrm{added.} \mathrm{The} \mathrm{mixture} \mathrm{was} \mathrm{stirred,} \mathrm{and} \mathrm{the} \mathrm{solution}$ was left standing for $16 \mathrm{~h}$. Then, the mixture was filtered. The calcium analysis was conducted in an atomic absorption spectrophotometer, and the potassium analysis was conducted in a flame photometer (Mehlich, 1953).

To evaluate the available phosphorus in the soil, $5 \mathrm{~g}$ of sample was weighed, and $50 \mathrm{~mL}$ of a solution of $0.0125 \mathrm{~mol} \mathrm{~L}^{-1} \mathrm{H}_{2} \mathrm{SO}_{4}+0.05 \mathrm{~mol} \mathrm{~L}{ }^{-1} \mathrm{HCl}$ (Mehlich-1) was added. The soil phosphorus availability was determined using a dilute ammonium molybdate solution, 3\% ascorbic acid and a spectrophotometer (HACH- DR6000 UV/Vis), at $660 \mathrm{~nm}$ (Raij, 1978).

The soil nitrogen was extracted in a microwave digestion system. First, $0.250 \mathrm{~g}$ of a soil sample was weighed and transferred to $60 \mathrm{~mL}$ vessels, and then $7 \mathrm{~mL}$ of $\mathrm{H}_{2} \mathrm{SO}_{4}$ and $2 \mathrm{~mL}$ of $30 \% \mathrm{H}_{2} \mathrm{O}_{2}$ were added. The amount of soil nitrogen was determined using a UV spectrophotometer (HACH- DR6000 UV/Vis), according to the Nessler method.

To analyze the soil exchangeable acidity $(\mathrm{H}+\mathrm{Al}), 5 \mathrm{~g}$ of a soil sample was weighed, and 50 $\mathrm{mL}$ of $1 \mathrm{~mol} \mathrm{~L}^{-1} \mathrm{KCl}$ was added, shaken manually several times and allowed to stand for 30 minutes. The solution was filtered with filter paper and washed twice with $20 \mathrm{~mL}$ of a $\mathrm{KCl}$ solution. Six drops of $0.1 \%$ phenolphthalein were added to the filtrate, and the solution was titrated with $0.01 \mathrm{~mol} \mathrm{~L}^{-1} \mathrm{NaOH}$ (Gillman et al., 1983). The percent aluminum saturation $(\mathrm{m} \%)$ is expressed by the equation $\mathrm{m} \%=[\mathrm{mmolc} \mathrm{kg}-1(\mathrm{H}+\mathrm{Al}) \times 100] /\left[\mathrm{mmolc} \mathrm{kg}^{-1}\right.$ (CEC)], which indicates the aluminum toxicity in the soil.

To analyze the soil cation exchange capacity, $2 \mathrm{~g}$ of a soil sample was weighed, then $1 \mathrm{~g}$ of 
active charcoal and $100 \mathrm{~mL}$ of $\mathrm{HCl}\left(0.5 \mathrm{~mol} \mathrm{~L}^{-1}\right)$ were added. The mixture was stirred for approximately $30 \mathrm{~min}$ and vacuum filtered, and the filter was washed with distilled water and then with $100 \mathrm{~mL}$ of a calcium acetate solution (to a final volume of $250 \mathrm{~mL}$ ). Finally, 6 drops of $0.1 \%$ phenolphthalein were added, and the solution was titrated with $0.1 \mathrm{NaOH}$ mol $\mathrm{L}^{-1}$ (Gillman et al., 1983).

For total organic carbon analysis of the soil, a sample of approximately $100 \mathrm{mg}$ was weighed. The organic carbon determinations were performed using a TOC-VCPH (Shimadzu) analyzer coupled to a solid sample module SSM-5000A (Shimadzu), according to the methodology provided by the manufacturer.

\section{Results and Discussion}

To evaluate any possible changes in the soil's attributes, the soil samples (control and after each bioherbicide application step) were collected and analyzed. Table 1 shows the soil characteristics before the start of the experiments (Time zero). It is important to emphasize that the application of the extracts onto the weeds causes the immediate contact of the bioherbicide with the soil. The influence of aqueous extracts containing the prospective bioherbicide on the soil was verified by ANOVA. The soil chemical analysis results from after the application and incorporation of the bioherbicide are shown in Table 2.

Table 1. Soil attributes before the experiments.

\begin{tabular}{cccccccccc}
\hline & $\mathbf{p H}$ & $\mathbf{p H}$ & $\mathbf{m}$ & $\mathbf{K}$ & $\mathbf{P}$ & $\mathbf{C a}$ & $\mathbf{N}$ & $\mathbf{C E C}$ & TOC \\
\hline & $\left(\mathrm{H}_{2} \mathrm{O}\right)$ & $\left(\mathrm{CaCl}_{2}\right)$ & $\%$ & $----\mathrm{mg} \mathrm{dm}^{-3}---$ & $\mathrm{cmol} \mathrm{dm}^{-3}$ & $\mathrm{mg} \mathrm{kg}^{-1}$ & $\mathrm{mmolc} \mathrm{kg}^{-1}$ & $\mathrm{~g} \mathrm{~kg}^{-1}$ \\
Time zero* & 5.82 & 5.22 & 4.2 & 2.13 & 0.22 & 25.17 & 1951.6 & 85.76 & 5.48 \\
\hline
\end{tabular}

*Before the first application of the bioherbicide. $\mathrm{m} \%=$ percent aluminum saturation. $\mathrm{CEC}=$ Cation Exchange Capacity. TOC $=$ Total Organic Carbon.

Table 2. Soil attributes after successive, accumulative applications of the extracts containing the bioherbicide in comparison to the control vase.

\begin{tabular}{ccccccccc}
\hline Attribute & DAA15 & DAA15* & DAA30 & DAA30* & DAA45 & DAA45* & DAA60 & DAA60* \\
\hline $\mathrm{pH}$ & $5.86 \pm 0.05 \mathrm{a}$ & $5.89 \pm 0.04 \mathrm{a}$ & $5.80 \pm 0.06 \mathrm{a}$ & $5.64 \pm 0.06 \mathrm{~b}$ & $5.53 \pm 0.34 \mathrm{a}$ & $5.60 \pm 0.06 \mathrm{a}$ & $5.32 \pm 0.20 \mathrm{a}$ & $5.54 \pm 0.06 \mathrm{a}$ \\
$\left(\begin{array}{c}\left.\mathrm{H}_{2} \mathrm{O}\right) \\
\mathrm{pH}\end{array}\right.$ & $5.20 \pm 0.18 \mathrm{a}$ & $5.10 \pm 0.04 \mathrm{a}$ & $5.04 \pm 0.02 \mathrm{a}$ & $5.04 \pm 0.03 \mathrm{a}$ & $5.18 \pm 0.30 \mathrm{a}$ & $5.28 \pm 0.04 \mathrm{a}$ & $5.06 \pm 0.09 \mathrm{a}$ & $5.05 \pm 0.04 \mathrm{a}$ \\
$\left(\mathrm{CaCl}_{2}\right)$ & & & & & & & \\
$\mathrm{m}$ & $2.9 \mathrm{a}$ & $4.2 \mathrm{a}$ & $2.2 \mathrm{a}$ & $1.7 \mathrm{a}$ & $21.4 \mathrm{a}$ & $2.2 \mathrm{~b}$ & $1.5 \mathrm{a}$ & $0.3 \mathrm{~b}$ \\
$(\%)$ & & & & & & & \\
$\mathrm{P}$ & $0.24 \pm 0.06 \mathrm{a}$ & $0.11 \pm 0.01 \mathrm{~b}$ & $0.23 \pm 0.03 \mathrm{a}$ & $0.15 \pm 0.01 \mathrm{~b}$ & $0.20 \pm 0.06 \mathrm{a}$ & $0.19 \pm 0.01 \mathrm{a}$ & $0.19 \pm 0.05 \mathrm{a}$ & $0.18 \pm 0.01 \mathrm{a}$ \\
$\left(\mathrm{mg} \mathrm{dm}^{-3}\right)$ & & & & & & & & \\
$\mathrm{K}$ & $2.90 \pm 0.20 \mathrm{a}$ & $2.60 \pm 0.10 \mathrm{a}$ & $3.00 \pm 0.20 \mathrm{a}$ & $2.76 \pm 0.25 \mathrm{a}$ & $3.06 \pm 0.15 \mathrm{a}$ & $2.70 \pm 0.20 \mathrm{a}$ & $2.30 \pm 0.10 \mathrm{a}$ & $2.30 \pm 0.26 \mathrm{a}$ \\
\hline$\left(\mathrm{mg} \mathrm{dm}^{-3}\right)$ & & & & & & & & \\
\hline
\end{tabular}




\begin{tabular}{|c|c|c|c|c|c|c|c|c|}
\hline $\begin{array}{c}\mathrm{Ca} \\
\left(\mathrm{cmol} \mathrm{dm}^{-3}\right)\end{array}$ & $17.32 \pm 0.95 \mathrm{a}$ & $22.65 \pm 0.87 \mathrm{a}$ & $17.2 \pm 1.38 \mathrm{a}$ & $15.76 \pm 0.98 \mathrm{a}$ & $15.95 \pm 0.83 \mathrm{a}$ & $15.44 \pm 0.84 a$ & $22.60 \pm 2.10 \mathrm{a}$ & $19.56 \pm 1.56 b$ \\
\hline $\begin{array}{c}\mathrm{N} \\
\left(\mathrm{mg} \mathrm{kg}^{-1}\right)\end{array}$ & $825.6 \pm 2.08 \mathrm{a}$ & $828.3 \pm 1.53 a$ & $466.3 \pm 1.52 \mathrm{a}$ & $465.3 \pm 1.53 \mathrm{a}$ & $924.3 \pm 2.52 \mathrm{a}$ & $928.3 \pm 1.54 \mathrm{a}$ & $1184.3 \pm 1.53 \mathrm{a}$ & $1187.3 \pm 3.60 \mathrm{a}$ \\
\hline $\begin{array}{c}\text { CEC } \\
\left(\mathrm{mmolc} \mathrm{g}^{-1}\right)\end{array}$ & $31.06 \pm 2.71 \mathrm{a}$ & $28.50 \pm 0.90 \mathrm{a}$ & $49.0 \pm 5.00 \mathrm{a}$ & $57.50 \pm 1.45 b$ & $45.69 \pm 2.87 \mathrm{a}$ & $39.20 \pm 1.75 b$ & $52.36 \pm 2.90 \mathrm{a}$ & $57.80 \pm 0.98 b$ \\
\hline $\begin{array}{c}\text { TOC } \\
\left(\mathrm{g} \mathrm{kg}^{-1}\right)\end{array}$ & $6.16 \pm 0.61 \mathrm{a}$ & $6.36 \pm 0.02 \mathrm{a}$ & $6.09 \pm 0.06 \mathrm{a}$ & $5.61 \pm 0.06 \mathrm{~b}$ & $6.00 \pm 0.28 \mathrm{a}$ & $5.42 \pm 0.13 b$ & $6.03 \pm 0.50 \mathrm{a}$ & $5.53 \pm 0.07 \mathrm{a}$ \\
\hline
\end{tabular}

*Control sample. Means that share the same letter in each attribute line do not differ significantly by Tukey's test $(\mathrm{P}<0.05)$. $(\mathrm{n}=3) . \mathrm{m} \%=$ percent aluminum saturation. $\mathrm{CEC}=$ Cation Exchange Capacity. TOC $=$ Total Organic Carbon.

\section{$3.1 \mathrm{pH}$}

In general, the mean $\mathrm{pH}$ values did not show significant differences during the application and incorporation of the bioherbicide (from 15 to 60 days of the experiment). Caires et al. (2008) evaluated the behavior of soybean in acidic soils, noting that the decrease in exchangeable $\mathrm{Al}^{3+}$ in soil after liming does not change the concentration of $\mathrm{Al}^{3+}$ in roots and soybean leaves. In general, the production of soybean grains is not influenced by liming due to the low toxicity of aluminum and because acidic soils stimulated root growth. In our study, with the evaluation intervals (15-60 days) corresponding to the 1st, 2nd, 3rd and 4th application of the bioherbicide, it was noticed that a larger number of applications within the pre-established intervals did not contribute to the increase of soil acidity.

\subsection{Nitrogen}

Statistically, there was no difference between the means of any of the determinations of the experimental and control soils. Considering the nitrogen cycle and the consumption of this nutrient as the plants grow, it can be concluded that, despite the successive applications of the bioherbicide to the weeds, the nitrogen levels equaled those in the control vase.

Therefore, the levels of nitrogen in all the soil samples were close, and we can conclude that any contact between the soil and the extracts did not change the characteristics of the soil.

\subsection{Exchangeable Aluminum}

Changes in the soil $\mathrm{pH}$ in no-tillage systems affect the solubility of aluminum, changing its absorption by plants. However, increases in the organic matter levels in this system can promote the reduction of aluminum toxicity due to surface complexation and complexation in the soil solution. Aluminum interacts with organic acids of low molecular mass and with humic acids and fulvic acids to form soluble or insoluble organic complexes, depending on the type of acid and the $\mathrm{pH}$ (Zambrosi, Alleoni and Caires, 2007).

The acidity of the soil at DAA45 was approximately 8 times higher than that obtained after the first application of the bioherbicide. The percent aluminum saturation (21.4\%) was high, indicating that there was possible damage to the soil. According to Osaki (1991), a percent aluminum saturation of up to $5 \%$ is considered very low and not harmful to the soil. Values of 
5 to 10 are low and slightly harmful. m\% between 10.1 to $20 \%$ is moderately harmful, whereas 20.1 to $45 \%$ is harmful; $m>45 \%$ is highly harmful.

By analyzing the bioherbicide-treated soil, it is possible to conclude that the extracts do not always persist past the 15-day interval, as can be observed by comparing DAA45, when the percent aluminum saturation was high, to DAA60, when the percent aluminum saturation returned to very low levels (1.5). Therefore, because it is a natural compound, the degradation process of the bioherbicide in the soil may have been accelerated by external factors such as temperature that changed its persistence throughout the experiment.

\subsection{Cation Exchange Capacity (CEC)}

The cation exchange capacity of a soil is linked to the retention capacity and availability of the nutrients to the plants.

The mean CEC of the DAA30, DAA45 and DAA60 samples were significantly different from those of the control soil. The control soil did not receive any bioherbicide, but the availability of nutrients is related to the number of plants that develop and to the proportion of those that are well-developed. Thus, the cation exchange capacity of the soil is a nutrient release mechanism that is controlled by the soil and depends on the nutritional needs of all the plants in the system. The soil analysis for DAA15 was not significantly different from the control, probably because, in this stage, both the treated and control soils had plants in developmental stages, and the inhibitory process caused by the bioherbicide only affects later steps in their development. Thus, there was no difference in the availability of nutrients.

In general, the variations in the CEC did not indicate any decrease caused by the contact of the extracts and the soil, since there was not a proportional decrease in the CEC levels as the number of extract applications increased.

\subsection{Phosphorus Availability}

Among samples from the same collection interval, only the soils collected from the first periods showed significant differences in their phosphorus availabilities. Initially, the plants in the control vase were better developed and absorbed more nutrients from the soil. This is exemplified by the control vases having less available phosphorus than the vases treated with the bioherbicide. These smaller values show that the plants subjected to the extracts absorbed fewer nutrients from the soil than those not treated with the extracts. However, the control and treated groups had equivalent phosphorus availabilities in the DAA45 and DAA60 samples, possibly because the weeds were already inhibited (the death of the weeds was evident), and therefore their consumption of nutrients was negligible. The plants in the control vases had good development in the soil and did not show signs of excessive consumption of this nutrient.

\subsection{Calcium and Potassium}

The development and productive performance of agricultural crops in acidic soils may be limited because of calcium and potassium deficiencies. However, the use of soil acidity correctives or of soil liming techniques with low magnesium correctives may have limited 
beneficial effects on the soil and cause a nutritional imbalance in the plants (Medeiros et al., 2008). In our experiment, no symptoms of the nutritional deficiency of these nutrients were observed in the soybean crop.

Statistical differences between the mean calcium contents were observed only in the soil at DAA60. The lower levels of calcium in the treated soil compared to those in the control vase shows that, in this stage of the experiment, the soil in the control vase still had a consumption of this element, since there were still plants in development. Evaluation of the system at this stage of the experiment (60 days) showed that the weeds were already dead or were poorly developed in contrast to the plants in the control vase, indicating that the nutrient absorption had already been impaired.

In general, the extracts did not interfere with the availability of calcium and potassium in the soil, since the obtained levels were statistically equivalent.

\subsection{Total Organic Carbon (TOC)}

It was not possible to consider whether the contact of the extracts and the soil had a direct effect on the variation in the soil carbon contents, so any variations in the carbon content were attributed to the environmental conditions (wind, climate, location, etc.) in which the experiment was carried out.

The slight increase in the carbon levels likely arose from the dry matter coming from the decomposition of the leaves that reached the soil. Any organic matter present in the soil increases the buffering power of the soil and reduces the dangers of mineral imbalances. At DAA60, most of the weeds combated by the bioherbicide are already dead, and the soybean is already well developed, (i.e., in the end of its cycle and producing new seeds). The leaves falling from the soybean, the remains of small insects and the accumulation of material (small branches and leaves) from the weeds increased the carbon levels in this stage through decomposition.

In general, the main changes in the soil's characteristics are related to the CEC and the exchangeable acidity. In all the experiments, the CEC of the soil varied throughout the experiment without showing strong trends with the number of applications. For the exchangeable acidity, subsequent application of the extracts generally did not increase the toxicity of the soil, revealing the low persistence of the bioherbicide in the soil. The variations in the other analyzed attributes were probably the result of the dynamics of the plants in the system and the absorption of nutrients by the plants.

\section{Conclusion}

In general, the soil acidity did not change significantly during these herbicide experiments, which thus caused no damage to the development of soybean plants. The variations in the soil nutrient levels correlated well with the levels of organic matter, and the cation exchange capacity favored the availability of nutrients at all stages of the study. Thus, the herbicide did not affect the soil fertility characteristics, and it consequently promoted the development of the plants. A statistical data analysis showed that the $\mathrm{pH}$ and the levels of phosphorus, 
calcium and potassium did not have a decreasing or increasing trend during the sequential incorporation of the bioherbicide extracts into the soil.

\section{Acknowledgements}

The authors would like to acknowledge FAPEMA (Maranhão Foundation for the Protection of Research and Scientific and Technological Development), CNPq (National Council for Scientific and Technological Development) process number 306715/2013-9, FAPESP (São Paulo Research Foundation) process number 2013/13093-7 and NAP 2012-CiTecBio, Provost for Research, University of São Paulo.

\section{References}

Andrade, S. A. L. et al. (2010). Biochemical and physiological changes in Jack-bean under mycorrhizal symbiosis growing in soil with increasing $\mathrm{Cu}$ concentrations. Environmental and Experimental Botany, 68, 198-207. http://dx.doi.org/10.1016/j.envexpbot.2009.11.009

Associación Latinoamericana De Malezas - Alam. (1974). Recomendaciones sobre unificación de los sistema de evaluación em ensayos de control de malezas, ALAM, 1(1), $35-38$.

Caires, E. F. et al. (2008). Soil acidity, liming and soybean performance under no-till. Scientia Agrícola, 65, 532-540. https://doi.org/10.1590/S0103-90162008000500013

Empresa Brasileira De Pesquisa Agropecuária - Embrapa. (2009). Fitorremediação de solos com resíduos de herbicidas. Aracajú: Embrapa Tabuleiros Costeiros, 32.

Fassbender, H. W. (1975). Química de suelos com enfase em suelos de América Latina. Turrialaba: IICA., 398.

Gillman, G. P. et al. (1983). A comparison of methods used for determination of cátion Exchange capacity. Communications in Soil Science and Plant Analysis, 14(11), 1005-1015. https://doi.org/10.1080/00103628309367428

Medeiros, J. C. et al. (2008). Relação cálcio: magnésio do corretivo da acidez do solo na nutrição e no desenvolvimento inicial de plantas de milho em um Cambissolo Húmico Álico. Semina: Ciências Agrárias, 29(4), 799-806.

https://doi.org/10.5433/1679-0359.2008v29n4p799

Mehlich, A. (1953). Determination of $\mathrm{P}, \mathrm{Ca}, \mathrm{Mg}, \mathrm{K}, \mathrm{Na}$ and $\mathrm{NH}_{4}$. Raleigh: North Carolina Soil Testing Division, 195B.

Oliveira, M. F., \& Brighenti, A. M. (2011). Comportamento dos herbicidas no ambiente. In Oliveira Júnior, R. S.; Constantin, J.; Inque, M. H. (Ed.), Biologia e manejo de plantas daninhas, 264-364. Curitiba: EMBRAPA.

Osaki, F. (1991). Calagem e adubação. Campinas: Instituto Brasileiro de Ensino Agrícola., 503.

Raij, B. Van. (1978). Seleção de métodos de laboratório para avaliar a disponibilidade de 
fósforo em solos. Revista Brasileira de Ciência do solo, 2, 1-9.

Silva, D. F., \& Rezende, M. O. O. (2016). Microwave-assisted extraction of phenolics compounds from Canavalia ensiformis leaves: preparation and evaluation of prospective bioherbicide on control of soybean weeds. International Journal of Engineering and Applied Sciences, 3, 106-111.

Singh, A., \& Ghoshal, N. (2013). Impact of herbicides and various soil amendments on soil enzymes activities in a tropical rainfed agroecosystem. European Journal of Soil Biology, 54, 56-62. http://dx.doi.org/10.1016/j.ejsobi.2012.10.003

SOCIEDADE BRASILEIRA DA CIÊNCIA DAS PLANTAS DANINHAS - SBCPD. (1995). Procedimento para instalação e análise de experimentos com herbicidas. Londrina: SBPCD., 42.

Yamashita, O. M. et al. (2009). Fatores ambientais sobre a germinação de Emilia sonchifolia. Planta Daninha, 27(4), 673-681. http://dx.doi.org/10.1590/S0100-83582009000400005

Zambrosi, F. C. B., Alleoni, L. R. F., \& Caires, E. F. (2007). Teores de alumínio trocável e não trocável após calagem e gessagem em latossolo sob sistema plantio direto. Bragantia, 66(3), 487-495. https://doi.org/10.1080/00103628309367428

\section{Copyright Disclaimer}

Copyright for this article is retained by the author(s), with first publication rights granted to the journal.

This is an open-access article distributed under the terms and conditions of the Creative Commons Attribution license (http://creativecommons.org/licenses/by/4.0/). 